\title{
A Disaggregated Econometric Analysis of Domestic Investment in Bangladesh: Issues and Challenges
}

\author{
Md. Raihan Islam ${ }^{1}$
}

\begin{abstract}
This paper tries to assess the degree of influences of the components of domestic investment on it and to examine their causal relationships associated with them at the disaggregated level in Bangladesh so that the policy makers could formulate appropriate policies regarding the issue. In doing so, the domestic investment function has been estimated.The pre-estimating techniques (the Chow test, the Coppock Instability Index, the Jarque-Bera test, the correlation matrix) confirm that there is no structural break point of the data series in 1990 and they are more instable during pre-liberalization (1990). All the variables are positively correlated and majorly they are normally distributed for parametric estimation. In econometric analysis, the results of unit root tests (the ADF, the D-F (GLS), the Phillips-Perron and the correlogram tests) show that the data of the variables of the domestic investment function have been found non-stationary at their levels as the null hypotheses are insignificant. But, they have all been found stationary after the first difference. That is, the variables have been integrated of order one I(1). The Johansen's Maximum Likelihood (ML) cointegration results show that there are 2 (two) long run stable cointegrating relationships between the pair-wise variables of domestic investment function. The estimated coefficients indicate that the GDP growth rate, FDI, real export and domestic credit have the positive impact on the domestic investment in Bangladesh of which real export affects it significantly. On the other hand, financial intermediation and human capital have negative impact on domestic investment but they are insignificant. The Wald test also confirms that the coefficients are jointly insignificant but some of them may be significant individually for domestic investment in Bangladesh. The VECM results show that the long run causalities exist between GDP growth rate, financial intermediation, real exports, human capital and domestic credit to the domestic investment. The short run effects exist between domestic investment and financial intermediation. There is short run dynamics to the long run equilibrium among GDP growth rate, real export, human capital to domestic investment otherwise, a divergence relation exist. The VAR estimation results indicate that the long run positive elasticities exist between real exports, domestic credit availability to domestic investment while long run negative elasticities exist between financial intermediation and human capital to domestic investment. The short run elasticities exist between GDP growth rate, FDI, financial intermediations, real exports and human capital to domestic investment in Bangladesh. Results of Granger causality test show that there are bidirectional causalities between pair-wise real export and domestic credit to domestic investment as they cause each other to grow. Otherwise, unidirectional causality exists. The response of all variables is either positive or negative in the short run but in the long run they all are responded towards the domestic investment in Bangladesh. The variance decomposition shows that the volatility of domestic investment is mainly caused by its own variation, as it always accounts for major portion (above $50 \%$ ) of the fluctuations. Finally, the robustness of the results has been justified with the popular postestimation model diagnostic tests. The analysis of this paper indicates that most of the factors of investment are unfavorable for the domestic investment in Bangladesh that should be addressed properly.
\end{abstract}

\section{Introduction}

Investment has acquired considerable emotive force in an economy. It is viewed as beneficial to employment creator-as it brings about economic growth and economic development in the long run. It can be termed as capital flowing from a firm or individual within the country or in one country to a business or businesses in another country involving a share of at least $10 \%$. Investment is generally classified into four major components: the private domestic investment, the public domestic investment, the foreign direct investment and the portfolio investment. Private domestic investment refers to gross fixed capital formation plus

1 Assistant Professor of Economics, Officer on Special Duty, Directorate of Secondary and Higher Education Bangladesh, Dhaka, Ministry of Education, Bangladesh \& PhD Fellow, Institute of Bangladesh Studies, University of Rajshahi, Rajshahi, Bangladesh.Email: raihan14131@gmail.com 
net changes in the level of inventories whereas; public investment includes investments by the government of a country and public enterprises on social and economic infrastructure, real estate and tangible assets. The combination of private and public investment is normally referred to as gross fixed capital formation while the tangible asset is referred to as direct foreign private investment (Perkins et al., 2001, pp. 522-523). The issue of economic prosperity is often linked to domestic investment i.e. the gross internal capital formation of a country.The issue has been argued considerably in the development and economic growth literature for many years. Many researchers have conducted studies to investigate the fundamental theories of domestic investment on economic growth and the benefits and costs of investment in developing countries. Most of them agree that there exists a positive causal relationship between domestic investment and economic performance, either in the short run or in the long run, or both. Diversified relationships may exist between domestic investment and FDI. FDI again helps to overcome capital shortage in the host countries and complements domestic investment when FDI flows to high risk areas or new industries where domestic investment is limited (Noorzoy, 1979). When FDI occurs in resource industries, domestic investment related industries may be stimulated. There have been different strands of theoretical and empirical studies aimed at investigating the relationship among domestic investment and in their various components at the disaggregated level both in developed and developing countries. The nexus of domestic investment and their various components has been the subject of much debate among development specialists, researchers, aid donors in Bangladesh. This paper however, tries to assess the influences of various components of domestic investment on it and the causality among them at the disaggregated level in Bangladesh. In this context, the sample of this study is spanned with 42 annual observations (1972 -2013). For empirical analysis, improved econometric data analysis techniques have been used appropriately throughout this paper.

\section{Statement Of The Problem}

Investment is the nuclear for economic growth of a country. Investment position of Bangladesh is however very poor either for domestic or foreign investment. Domestic investment in Bangladesh suffers with the scarcity of capital formation. Due to the wide gap of saving and investment local entrepreneurs look for foreign capital. Domestic investment depends on its various components. The impact of the different components of domestic investment and their interrelationships are not always in the same direction in Bangladesh. Some components affect them positively while others affect negatively. Some are significant while others are not. Again, the nature and trend of those components may have different and negative so that they could hardly affect domestic investment of the country. Therefore, it has also become the burning issue to analyze the influences of different components of domestic investment on it as well as their causal relationships at the disaggregated level in Bangladesh. Theory states that capital formation proxy of domestic investment mainly depends on the savings of the country. The gross domestic saving stands to $21.39 \%$ in $2013-14$, whereas it was $20.25 \%$ of GDP in 2005-06. The gross national savings rate stands to $30.54 \%$ of GDP in 2013-14, while it was $27.67 \%$ in 2005-06 in Bangladesh. The amount of gross domestic investment rises to $28.69 \%$ of GDP in 2013-14, while it was $24.65 \%$ in the year 2005-06. There is a positive sign in this case but, a very remarkable negative gap between saving-investment is seen in Bangladesh and the gap is going to increase with the span of time. The gap is also clearly observed between the public-private saving-investments in Bangladesh with rising trend over the period. Because of low domestic saving rates, gross capital formation has slowed down consistently in the recent years, hovering at around 24\% of GDP. The main reason behind the slowing down of investment has been a secular decline in public investment which, as proportion of GDP, fell to a historic low of 4.6\% in FY2008-09 from 6.2\% in FY2004-05 (BER, 2014). As public investment has not increased, the private investment does not play the significant role in Bangladesh. The large-scale investment in infrastructure sector including power and the speedier implementation of Annual Development Programme (ADP) pushes up the level of public investment in FY 2011-12. During this period, gross investment accelerates to 25.45 percent of GDP from 25.15 percent in the previous fiscal year. Of this, gross private investment marginally goes down to 19.14 percent of GDP, from 19.51 percent of GDP in FY2010-11. However, public investment in Bangladesh is increased to 7.30 percent of GDP in 2013-14 from 5.64 percent in FY2010-11. The targeted GDP growth in the present and in the coming years will require a considerable increase in the investment- perhaps worth almost an additional $2 \%$ of GDP every year. The shortfall rises to $\$ 9.40$ billion in $2013-14$, when the cumulative shortfall stands at \$ 28 billion. The huge investment need would require resource mobilization by increased public savings through higher revenue earnings, and increased private savings- by both individuals and the corporate sector. There is also a clear gap between targeted and achieved investment in Bangladesh. In 2013-14, the required investment was 49.69 billion US \$ but the actual investment is 30.40 billion US $\$$ in the same year (BER, 2014). However, since available domestic saving will be insufficient to meet the needs of increased investment, the country will need larger doses of capital inflow or instigating massive capital formation in the country to meet the resource shortfall. All these create an interest for the author to empirically investigate the 
impact of various components of domestic investment on it and their causal relationship with a view to assisting policy making institutions.

\section{Objective of the Study}

The general objective of this paper is to provide a disaggregated econometric analysis of domestic investment and its various components in Bangladesh. From the above background this paper is guided by the following specific objectives:

i) to assess the current states of domestic investment in Bangladesh;

ii) to assess the degree of influences of the components of domestic investment on it;

iii) to measure the causal relationships among domestic investment and its various components;

iv) to identify the challenges regarding domestic investment in Bangladesh; and

v) to offer some policy recommendations regarding the issue.

\section{Review of the Literature}

This paper has studied a number of research works on supporting the relationship between domestic investment and its various components in both developed and developing countries including Bangladesh. Haque (2012) examines empirically the impact of public and private investment on economic growth. He develops a simple analytical model embodying the distinction between public and private investment and implements it using aggregate public and private gross capital formation data for Bangladesh during 1972-73 to 2010-11 period. He found that public and private investment impact positively economic growth in the short and long run process while private investment is more effective in the long run then public investment in Bangladesh. Tang et al. (2008) investigate the causal link between FDI, domestic investment and economic growth in China for the period 1988-2003. The results show that FDI has not only assisted in overcoming shortage of capital, it has also stimulated economic growth through complementing domestic investment in China. Qamarullah (2007) analyses the relationship between economic growth and private investment for the case of Bangladesh. The results indicate that there is a unidirectional causal relationship running from economic growth to private investment growth for Bangladesh for the period under consideration. Wadud (2005) examines the long-run relationship between saving and investment in Japan to assess capital mobility with VAR approach. Result confirms the short-run instability between saving and investment, but there remains one cointegration vector ensuring a long-run relationship between saving and investment. Islam et al. (2005) observe that the economy of Bangladesh has a steady growth of GDP and investments between 1974 and 2003. They find that there is a unidirectional causal relationship running from economic growth to investment growth for Bangladesh for the period under consideration. Kim and Seo (2003) provide empirical evidence on the dynamic relationship between inward FDI, economic growth and domestic investment in Korea for the period 1985-1999. Their finding does not support the view that FDI crowds out domestic investment in Korea. Matin (1987)attempts to obtain the effect of foreign capital inflow on domestic savings and the growth rate of savings. He finds that the effect of foreign capital inflow on domestic saving is very sensitive to the types of deflation and also the methods of estimation employed. He observes that positive effect of foreign capital inflow rate is no longer statistically significant.

\subsection{Savings and Domestic Capital Formation in Bangladesh}

\section{Present Trend Of Investment In Bangladesh}

Bangladesh's savings rate has experienced a steady and substantial rise over the past decades. The gross domestic savings has increased from 2.05\% of GDP in 1980.Domestic savings has increased from 18.38 $\%$ of GDP in 2002 to $21.17 \%$ of GDP in 2013, which amounts to an average annual growth of $19.5 \%$. The national savings rate in Bangladesh was 27.67 \% of GDP in 2005-06 and it rises to 30.54\% of GDP in 2013-14. The private savings rate in Bangladesh is remained steady at $18 \%$ over the period against the public savings (average $1.35 \%$ ) (BER, 2014). These are the poor scenario of the domestic and national savings in Bangladesh. The importance of capital formation of a country is inevitable for the domestic investment which may be the engine of economic growth. The actual scenario of the gross capital formation in Bangladesh from the very beginning of the independence was only US\$295.40 million in 1972 but with the passage of time the figure stands at 42581.72 million US\$ in 2013. In 1990, the gross capital formation was 5138.198 million US\$; this was the rising point and the tendency is seen to date in Bangladesh (WDI, 2014). But, it is a matter of fact that the rate of gross capital formation in Bangladesh is very poor to enhance domestic investment.

\subsection{Investment Trend and Saving-investment Gap in Bangladesh}

A deeper analysis shows that public sector investment is much smaller compared to private sector investment and it is growing very slowly. The gross investment was $21.6 \%$ of GDP in the year 1997 while the figure rose to $24.4 \%$ in the year 2004. The gross investment further increased continuously in Bangladesh over 
the period and stands to $28.69 \%$ of GDP in the year 2013. On the other hand, public investment figure actually declined as percentage of GDP. This percentage figure was 6.4\% of GDP in the year 1997, while it fell at $5.9 \%$ in the year 2004 and it is increased little to $7.30 \%$ of GDP in 2013. The private investment in Bangladesh is increased over the period but the rate of growth is very slow and the figure stands at $21.39 \%$ in 2013 (BER, 2014). It should be noted that the level of investment (public and private) in the economy of Bangladesh is poor compare to other economies of comparable per capita income. A developing economy like Bangladesh needs to plough back more than $40 \%$ of the GDP for investment. The agro base industry, textile, chemical and service industries are the major investing sectors locally of which service sector is the highest investing area (Tk. 116714.1 million) in Bangladesh in 2013-14.The sector wise domestic investment in the fiscal year 2013-14 in Bangladesh indicates that agro base industry, textile, chemical and service industry are the major domestic investment sectors in Bangladesh while the service industry occupies the highest attention a drastic increase to $42 \%$ which is $13 \%$ more than that of the fiscal year 2011-12 in Bangladesh (BER, 2012). It is mainly due to the political unrest in Bangladesh from 2012-13, which is continuing to date. High rates of saving and investment are essentially prerequisites for high economic growth. But, domestic saving in Bangladesh, on which investment greatly depends, has remained stagnant at around $20.0 \%$ of GDP in the most recent years. Public saving has always been negative in the country as the growing fiscal deficits in successive annual budgets. Domestic saving in the country therefore comes essentially from the private sector. Private saving is however, low partly because of weak intermediation in the banking sector but largely due to low per capita income. Yet, the country needs a lot more resources to invest in physical infrastructure as well as for the development of power and gas sectors, which are among the major causes of the sluggish private investment in the country.

\subsection{Employment and Wage Rate in Bangladesh}

Labor market situation in Bangladesh is fragile as high population growth continues to expand the economically active population and privatized industries simultaneously lay off employees. Relatively high rates of inflation combined with high levels of unemployment may lower real wages. According to Bangladesh Labor Force Survey 2002-03 conducted by BBS, a labor force (above 15 years) of 4.43 crores (male 3.45 crores and female 0.98 crores) is engaged in a variety of professions. Agriculture accounts for $51.69 \%$ of employment; industry $13.56 \%$ and services $26 \%$. It is observed that highest $44.70 \%$ labor force is engaged in selfemployment, $20.09 \%$ of labor force was engaged as daily laborers and $13.77 \%$ as full time employed workers. $18.28 \%$ of labor force was engaged as unpaid family laborers. The economically active population of age 15 years and above in Bangladesh is 5.67 crores of which 5.41 crores (Male 3.79 and Female 1.62 crores) are engaged in different professions. In the Labour Force Survey 2005-06 economically active population (15 + age) was 4.74 crores (Male 3.61 and Female 1.13 crores) (L F S, 2010). Labourare being migrated from agriculture to other professions over the years. It is remarkable that the farm and non-farm employment is widened in the country with the passage of time. Being an individual sector, agriculture till now is playing a vital role as the main source of employment in Bangladesh. The labour force in Bangladesh is increased with increasing population but it is a matter of happiness female participation in labour force is also increased by manifolds in the country. It is however, massive challenge for Bangladesh to find work for over 2 million people who enter the labor force every year. Most of them engage in self-employment in low productive areas of the non-formal sector (BER, 2014).The nominal wage rate indexes are increased for the fiscal year 2004-05 to 2008-09. The index is decreased by 10.64 percent in 2009-10 compare to the previous year. It is further continuously upward rising trend from FY 2010-11 to FY 2012-13. Report further shows that WRI (wage rate index) is increased by 14.73 percent in 2012-13 while it was 11.89 percent in the previous fiscal year. The sectoral growth of WRI is increased in all sectors except manufacturing over 16.08 percent in 2012-13 of which fishery and manufacturing WRI are increased by 16.08 and 10.48 percent respectively. On the other hand, the WRI in agriculture and construction sectors are 21.44 and 16.73 percent in 2012-13 respectively. Yet, the WRI in Bangladesh is very low compare to other South Asian countries.

\subsection{Human Resource Development in Bangladesh}

Bangladesh has made significant achievements in the areas of education and health in the past thirty years, but many challenges remain because certain other elements for a strong capital base are missing. School enrollment rates have increased but these ratios are lower than those in any comparator countries of East and South Asia. HDI is increasing gradually and the population under poverty line is also decreasing. Both the fertility and mortality rate are decreasing over the year. Life expectancy of the citizen goes up from 56.9 in 1980 to 66.9 in 2010. Student enrolment in each sector as well as adult literacy rate is increasing over the year. But, tertiary enrolment remains low at about 7 percent, compared to 13.5 percent in India, 18 percent in Indonesia, 22 percent in China, and 30 percent in Malaysia (UNDP, 2010). Yet, Bangladesh has a low record of the technological innovation. The shortage of skilled workers is also a cause of concern. Adult illiteracy, despite improvements, remains high. The concerns about the quality of education are also remained. 


\subsection{Data and Sample Selection}

\section{Methodology}

The data for this study have basically been collected from the secondary sources, those are: the Statistical Yearbook of Bangladesh, Bangladesh Economic Review of various years, Bangladesh Economic Survey, and Economic Indicators of Bangladesh Bank. Data of this study have been obtained majorly from the World Development Indicators (WDI) of World Bank database and the Direction of Trade Statistics (International Monetary Fund). Other sources of data have also been used for the requirement of the estimations. Since, all the relevant variables are the macroeconomic in nature; the secondary data are obviously required to estimate the domestic investment function. The variables that have been used are: domestic investment proxy of gross capital formation, GDP growth rate, foreign direct investment, financial intermediation, country's real export, human capital and domestic credit availability. The collected data have frequently been transformed into logarithmic and generated in accordance with the requirement of the time series econometric analysis that has made the study more valid and reliable. Analyses of trends and characteristics of domestic investment and its various components have been made mainly in terms of constant data based on 2005. This is done for avoiding the inflationary effect in the data. The area of the study is the whole country with the disaggregated level discussion. The sample of this study has covered forty two (42) annual observations covering the period 1972 to 2013.

\subsection{Estimable Domestic Investment Function for Bangladesh}

A number of models have been employed in the literature to explain the factors of domestic investment, among these models; the neoclassical investment model and the accelerator investment model are important. This study has been considered the accelerator investment model for overcoming the drawbacks of the neoclassical investment model. Theoretically, most of the literatures pointed out that the variables (Growth rate of GDP, FDI, financial intermediation, exports, human capital, and domestic credit availability) contribute positively to the growth of domestic investment in developing countries (Lucus, 1998; Romer, 1990; Borensztein, et al., 1998; Levin and Beck, 2000). Specifically, on the basis of the existing literature and theories the domestic investment model for Bangladesh is given by the following multiple regression equation with logarithmic form:

$$
\ln d i=\delta_{0}+\delta_{1} \ln g r g d p+\delta_{2} \ln f d i+\delta_{3} \ln f i+\delta_{4} \ln r x+\delta_{5} \ln h c+\delta_{6} \ln d c+v .
$$

Where, $d i=$ domestic investment proxy of gross capital formation over GDP; $g r g d p=$ growth rate of real GDP; $f d i=$ foreign direct investment as a ratio of GDP; $r x=$ exports of goods and services as a ratio of GDP; $f i=$ financial intermediation as calculated by $\mathrm{M}_{2}$ as a ratio of GDP; $h c=$ human capital proxied by secondary school enrolment ratio ( $\%$ of gross enrolment); $c r=$ domestic credit availability as a ratio of GDP; and $v=$ error term. The data of the variables of domestic investment function has been transformed into natural logarithms because, the coefficients of the cointegrating vector can be interpreted as long run elasticities; the log first difference can be interpreted as growth rates; it reduces the heteroscedasticity problem from the model; and the log data tends to be stationary.

\subsection{Econometric Designs}

In order to fulfillment of the objectives and to test the hypotheses improved econometric analytical techniques with up to date available data have been carried out throughout this paper. The econometric procedure of this paper thus proceeds as: First, as the pre-estimation techniques, the procedures, the nature of the data distribution have been examined successively. One, the standard descriptive statistics are to be analyzed with the summary statistics. Two, if a time series contains trend, seasonality or some other systematic components, the usual summary statistics can be seriously misleading and should not be calculated. In the kvariable regression model, we shall have in all $k(k-1) / 2$ zero-order correlation coefficients. These $k(k-1) / 2$ correlations can be put into a matrix, called the correlation matrix R (Gujarati, 2012, pp. 937-938). Where, the subscript 1 , denotes the dependent variable $\mathrm{Y}\left(\mathrm{r}_{12}\right.$ means correlation coefficient between $\mathrm{Y}$ and $\mathrm{X}_{2}$ and so on) and where use is made of the fact the coefficient of correlation of a variable with respect to itself is always 1 ( $r_{11}$ $\left.=r_{22}=\ldots \ldots=r_{k k}=1\right)$. In this way the correlation among domestic investment, FDI, trade openness and GDP growth are to be examined. Three, There is one assumption of chosen CLRM that one should like to check, namely, the normality of the disturbance term $u_{t}$ that is, the $t$ and $F$ tests used before require that the error term follow the normal distribution. The J-B test of normality is an asymptotic, or large-sample, test. It is also based the OLS residuals. The test first computes the skewness and kurtosis measures of the OLS residuals. The value of the J-B statistic is expected to be 0 . If the computed $p$ value of the J-B statistic in an application is sufficiently low, which will happen if the value of the statistic is very different from 0 , one can reject the hypothesis that the residuals are normally distributed. But, the $p$ value is reasonably high, which will happen if the value of the 
statistic is close to zero, the normality assumption will not be rejected (Gujarati, 2012, pp. 147). Four, generally time series data suffers from structural break problem. The Chow test is essential for long run time series to identify parameter stability over the period of investigation. In this study, the period is broken by two subperiods such as pre liberalization (1972-1990) and post liberalization (1991-2013). Therefore, the Chow test is very much appropriate to apply to test the parameter stability. The Chow test is simply the F-test. If the value of computed F-statistic is greater than the critical value then we reject the null hypothesis (there is no significant change in the time series data between two periods) of structural stability is rejected, otherwise accepted (Maddala, 2001, pp. 173). Five, the pattern of stability of time series data during both periods (pre and postliberalization) as well as overall study is measured by the Coppock's Instability Index (1962). The coppock Instability Index thus, can be measured them by the following algebraic formula:

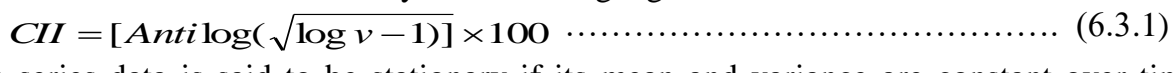

Second, any time series data is said to be stationary if its mean and variance are constant over time and the value of the covariance between two-time series does not depend on the actual time at which the covariance is computed (Gujarati, 1995). On the other hand, a series is non-stationary if it fails to satisfy any of the conditions, i.e. its mean, variance or covariance change overtime. The time series tend to exhibit non-stationary stochastic process is in the following form:

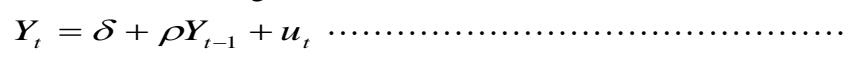

Where, $\delta$ is a constant, $\mathrm{u}_{t}$ is the stochastic error term. If the coefficient of $Y_{t-1}$, in fact equal to $1(\rho=1)$, then, $Y_{t}$ is said to have a unit root problem. In other words, $Y_{t}$ could be characterized as having a unit root and a drift (random walk with a drift. The time series property of each variable is investigated under a univariate analysis by implementing the ADF (Augmented Dickey- Fuller), D-F (GLS), PP test and the correlogram test for the unit root (non-stationarity) problem. One, the Augmented Dickey-Fuller test is used to test for the existence of unit roots and determine the order of integration of the variables. The tests are done both with and without a time trend. Akaike method is used to choose the optimal lag length, which is found to be 1 for all variables. The presence of a unit root problem which indicates non stationarity, cannot be rejected for levels of the variables at the $5 \%$ significance level. It may be also found in the first difference. However, the non-stationarity problem then may be vanished after second difference and so on. The ADF test however, requires modifying as:

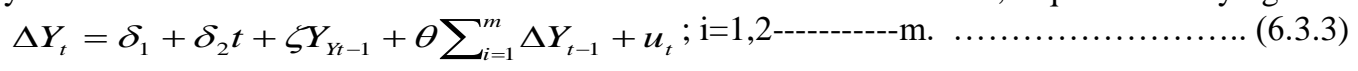

Where, $\mathrm{u}_{t}$ is assumed to be identical and independently distributed random variable. Two, the D-F (GLS) t-test is performed by testing the hypothesis $\mathrm{a}_{0}=0$ in the regression:

$$
\Delta y_{t}^{d}=\alpha_{0} y_{t}^{d}+\alpha_{1} \Delta y_{t-1}^{d}+\ldots \ldots \ldots \ldots \ldots+\alpha_{\rho} \Delta y_{t-\rho}^{d}+u_{t}
$$

Where $\mathrm{y}_{\mathrm{t}} \mathrm{d}_{\mathrm{i}}$ locally de-trended series $\mathrm{y}_{\mathrm{t}}$. The local de-trending depends on whether we consider a model with drift only or a linear trend. Thus the DF-GLS test is the popular solution to the problem of size distortions and low power of unit root tests. If the critical value of DF-GLS test is lower than the calculated value, the null hypothesis of existence of unit root problem accepted otherwise rejected and the data series are non-stationary. But, the data series may be stationary in the first or second difference. The critical values of DF-GLS test are shown by Elliott et al. (1996) for a model with linear trend (Maddala, 2001, pp. 550-551). Three, PhillipsPerron (1988) test is used to deal with serial correlation and heteroscedasticity. An important assumption of the DF test is that the error term $u_{t}^{\prime} \mathrm{s}$ is independently and identically distributed. The ADF test adjusts the DF test to take care of possible serial correlation in the error terms by adding the lagged difference terms of the regressand. The PP test is the t value associated with the estimated coefficient of $\rho^{*}$. The series is stationary if $\rho^{*}$ is negative and significant. The test is performed for all the variables where both the original series and the difference of the series are tested for stationarity. Four, the non-stationarity of time series data can be tested by using autocorrelation function (ACF) based on the so-called Correlogram test. The ACF at lag $k$, denoted by $\rho_{\mathrm{k}}$, is defined as:

$$
\hat{\rho}_{k}=\frac{\gamma_{k}}{\gamma_{0}}=\frac{\text { Co variance }}{\text { Variance }}=\frac{\sum\left(Y_{t}-\bar{Y}\right)\left(Y_{t+k}-\bar{Y}\right)}{n}=\frac{\sum\left(Y_{t}-\bar{Y}\right)^{2}}{n}
$$

Where, $n$ is the sample size and $\bar{Y}$ is the sample mean. Bartlett (1946) has shown that if a time series is purely random that is, if it exhibits white noise, the sample autocorrelation coefficients are approximately normally distributed with zero mean and variance $1 / n$. Following the properties of the standard normal distribution, the 95 percent confidence interval for any $\hat{\rho}_{k}$ will be, $\pm 1.96(1 / n)$. Thus, if an estimated $\hat{\rho}_{k}$ falls inside the interval $(-1.96(1 / n),+1.96(1 / n))$, the hypothesis cannot be rejected that the true $\hat{\rho}_{k}$ is zero. But, if it lies outside 
this confidence interval, the hypothesis can be rejected that the true $\hat{\rho}_{k}$ is zero. If none of the estimated correlations lies in the interval, the estimated autocorrelation shown by the table will be statistically significant (Gujarati, 2011). Third,in the event of the non-stationarity of each variable, the cointegrating relationship among variables (tendency for variables to move together in the long run) is studied by the Johansen-Juselius procedure (Johansen 1988, Johansen-Juselius 1992, 1999) to overcome the associated problem of spurious correlation and misleading inferences. Johansen (1988) suggests a maximum likelihood procedure to obtain cointegrating vectors and speed of adjustment coefficient identifying the number of cointegrationvectors within the vector autoregressive (VAR) model. To identify the number of cointegration vectors, a likelihood ratio test of hypothesis is used. The following Vector Autogressive (VAR) model is the basis of multivariate cointegration of Johansen Maximum Likelihood approach:

$$
Z_{t}=A_{1} Z_{t-1}+-----A_{k} Z_{t-k}+u_{t}
$$

Here, $Z_{t}$ is an $\left(\begin{array}{lll}n & x & 1\end{array}\right)$ vector of $I(1)$ variables including both endogenous and exogenous variables. $A_{i}$ is an $(n x$ $n$ ) matrix of parameters, $u_{t}$ is $\left(\begin{array}{lll}n & x & 1\end{array}\right)$ vector of white noise errors. The equation (6.3.6) can be estimated by OLS because each variable in $\mathrm{Z}$ is regressed on the lagged values of its own and all other variables in the system. Since, $Z_{t}$ is assumed to be non-stationary, it is convenient to rewrite (6.3.6) in its first difference or error correction form as:

$$
\Delta Z_{t}=\Gamma_{1} \Delta Z_{t-1}+-----+\Gamma_{k-1} \Delta Z_{t t-k+1}+\Pi Z_{t-k}+u_{t}
$$

Where, $F_{j}=-\left(1-A_{1}-A_{2}----A_{i}\right),(i=1----k-1)$, and $\Pi=-\left(1-A_{1}-A_{2}---A_{k}\right)$

The specification (6.3.7) provides information about the short- run and long- run adjustments to the changes in $Z_{t}$ by

estimating $\Gamma$ and $\Pi$ respectively. Equation (6.3.7) differs from the standard first difference form of the VAR model by only the inclusion of the term $\Pi Z_{t-k}$. This term shows about the long- run equilibrium relationship between the variables in $Z_{t}$. Information about the number of cointegrating relationship among the variables in $Z_{t}$ is given by the rank of the number matrix $\Pi$. If the rank of the $\Pi$ matrix $r$ is $0<r<n$, there are liner combinations of the variables that are stationary. The matrix can be decomposed into two matrices $\alpha$ and $\beta$ such that $\Pi=\alpha \beta$, where $\alpha$ is the error correction term and measures the speed of adjustment in $\Delta Z_{t}$ and $\beta$ contains $r$ distinct cointegrating vectors. The cointegrating rank of the above matrics $r$, can be formally tested with the Maximum Eigenvalue test $(\lambda \max )$ and the Trace test $(\lambda$ trace). Fourth,If the data series are cointegrated, the ordinary least squares (OLS) method has been applied for functional estimation by minimizing its error term with sum and squares method. For $K$-variable case, the prominent matrix technique is to be applied for the estimation of the function. In case of multiple regressions or the $\mathrm{K}$ variable regression model, the ordinary least squares (OLS) method can be written more compactly in matrix notation as:

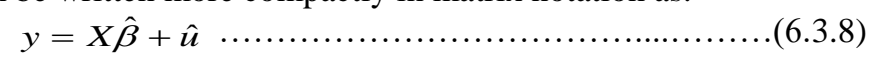

Where, $\hat{\beta}$ is a $K$ - element column vector of the OLS estimators of the regression coefficients and where $\hat{u}_{i}$ is an $n \times 1$ column vector $n$ residuals. As in the two and three variable models, in the $k$-variable case the OLS estimators are obtained by minimizing the residuals that gives, $\hat{u}=y-X \hat{\beta}$; Thus, by simple calculation,

$$
\hat{\beta}=\left(X^{\prime} X\right)^{-1} X^{\prime} y
$$

Where, $\left(X^{\prime} X\right)^{-1}\left(X^{\prime} X\right)=I$ is an identity matrix of order $(k \times k)$. Equation (6.3.9) is a fundamental result of the OLS

theory in matrix notation for the case multiple regression model. It shows the $\hat{\beta}$ vector can be estimated from the given data that provides the best linear unbiased estimator that is BLUE (Gujarati, 1995, pp. 287-288). The Wald testfor the multiple regression models to test the hypothesis $\beta_{i}=0$ we use this test statistics with the corresponding partial $\mathrm{r}^{2}$ substituted in the place of the simple $\mathrm{r}^{2}$. The test statistics has a $\chi^{2}$ distribution with $d . f$. $k$. The Wald test has a $\chi^{2}$-distribution with d. f. r. if the test statistics is significant at the level, rejecting the hypothesis of coefficient stability (Maddala, 2001, pp. 176-177). Fifth, the purpose of VECM model is to indicate the speed of adjustment from the short run dynamics to the longrun equilibrium state. The model is specified as: 


$$
\ln d i_{t}=\alpha+\lambda e_{t-i}+\sum_{i=1}^{n} \beta_{i} \ln g r g d p_{t-i}+\sum_{i=1}^{k} \delta_{i} \ln f d i_{t-i}+\sum_{i=1}^{r} \phi_{i} \ln f i_{t-i}+\sum_{i=1}^{p} \varphi_{i} \ln r x_{t-i}+\sum_{i=1}^{q} \lambda_{i} \ln h c_{t-i}+\sum_{i=1}^{s} \eta_{i} \ln c r_{t-i}+\varepsilon_{t}
$$

this specification, the variables are cointegrated if the parameter $(\lambda)$ of the error correction term is negative and statistically significant in terms of its associated-t value. In case of $\lambda$ being positive and statistically significant, still there exists a long run causality but with a divergence. Sixth, VAR methodology superficially resembles simultaneous equation modeling in that it is considered several endogenous variables together. But, each endogenous variable is explained by its lagged, or past, values in the model. In such models, some variables are treated as endogenous and some as exogenous or predetermined (exogenous plus lagged endogenous). The seeds of this model are shown in the Granger causality test.

The test involves estimating the following regressions on the basis of GRGDP and DI:

$$
\begin{aligned}
& \ln \operatorname{grgdp}_{t}=\sum_{i=1}^{n} \alpha_{i} \ln d i_{t-i}+\sum_{j=1}^{n} \beta_{j} \ln g r g d p_{t-j}+u_{1 t} \ldots \ldots \ldots \\
& \ln f d i_{t}=\sum_{i=1}^{m} \lambda_{i} \ln d i_{t-i}+\sum_{j=1}^{m} \delta_{j} \ln g r g d p_{t-j}+u_{2 t} \ldots \ldots \ldots \ldots
\end{aligned}
$$

Where, it is assumed that the disturbances $u_{1 t}$ and $u_{2 t}$ are uncorrelated. The first equation postulates that current lngrgdp is related to past values of GDPgrowth rate itself as well as of domestic investment, and the second equation postulates a similar behavior for $l n d i_{t}$. It is essentially, treated that GDP growth rate and domestic investment as a pair of endogenous variables. There are no exogenous variables in this system. This example is the illustrations of vector autoregressive model; the term autoregressive is due to the appearance of the lagged value of the dependent variable on the right-hand side and the term vector is due to the fact that are dealt with a vector of two (or more) variables (Gujarati, 1995, pp-746).

Seventh, Granger (1988) developed a test to check the causality between variables. Granger causality examines to what extent a change from past values of a variable affect the subsequent changes of the other variable. In order to obtain the estimated residuals $\epsilon_{\mathrm{t}}$, the Granger models with a dynamic error correction are as follows:

$$
\ln d i_{t}=\alpha+\lambda e_{t-i}+\sum_{i=1}^{m} \gamma_{i} \ln g r g d p_{t-i}+\sum_{i=1}^{r} \phi_{i} \ln f d i_{t-i}+\sum_{i=1}^{p} \varphi_{i} \ln f i_{t-i}+\sum_{i=1}^{q} \lambda_{i} \ln r x_{t-i}+\sum_{i=1}^{k} \ln h c+\sum_{i=1}^{n} \ln c r+\varepsilon_{t}
$$

Where, $\Delta$ indicates the difference operator, $\epsilon$ implies nonzero serially independent random error terms, and $\lambda_{t-i}$ is the lagged error correction term obtained from the long run cointegrating relations between the variables. The $F$ statistics are the Wald statistics for the joint hypothesis, no causal relationship. It means that, the null hypothesis is that $X_{t}$ does not Granger cause $Y_{t}$ and that $Y_{t}$ does not Granger cause $X_{t}$ in case of two variable regression model for example. Eighth, just as an autoregression has a moving average representation, a vector autoregression can be written as a vector moving average (VMA) model as:

$$
x_{t}=\mu+\sum_{i=0}^{\alpha} A^{i}{ }_{1} e_{i-1}
$$

Where, $\mu=(\bar{y} \bar{z})^{i}$ and the unconditional mean of $x_{i}$ is $\mu$. This equation is the VMA representation in that the variables are expressed in terms of the current and past values of the two types of shocks (i.e., $e_{1 t}$ and $e_{2 t}$ ). The VMA representation is an essential feature of Sim's (1980) methodology in that it allows tracing out the time path of the various shocks on the variables contained in the VAR model. Impulse response analysis (IRA) is performed in this study by giving a shock of one standard deviation ( \pm 2 S.E. innovations) to GDP growth rate, FDI, financial intermediations, real export, human capital and domestic credits to visualize the duration of their effects on the domestic investment in Bangladesh. Ninth, the variance decomposition analysis reveals that the variance of GDP growth is primarily caused by its own variance followed by the volume of its various components. It is to be noted that the role of different components in explaining the volatility of domestic investment is to be found to be more influential from the subsequent years. Finally, if the error term in one time period is correlated with the error term in the previous time period, there is first-order autocorrelation. Most of the applications in econometrics involve first rather than second- or higher-order autocorrelation. Two popular correcting autocorrelation methods are the B-G and the L-M test. One, to avoid some of the pitfalls of the Durbin-Watson $d$ test of autocorrelation, statisticians Breusch and Godfrey have developed a test of autocorrelation. Assuming a regression model where the error term $u_{t}$ follows the $\rho$ th order autoregressive, $A R(\rho)$ schemes as follows:

$$
u_{t}=\rho_{1} u_{t-1}+\rho_{2} u_{t-2}+------+\rho_{\rho} u_{t-\rho}+\varepsilon_{t}
$$

Where, $\epsilon_{\mathrm{t}}$ is a white noise error term. This is simply the extension of the $A R(1)$ scheme. This test is an alternative to the Q-Statistic for testing serial correlation.The null hypothesis of the B-G test is that there is no serial 
autocorrelation up to the specified number of lags. The number of observations multiplied by $\mathrm{R}^{2}$ is the BreuschGodfrey test statistic. $\boldsymbol{T} \boldsymbol{w o}$, in the multiple regression models to test the hypothesis $\beta_{i}=0$, we use this test statistics with the corresponding partial $r^{2}$ substituted in the place of the simple $r^{2}$. We have to substitute the multiple $\mathrm{R}^{2}$ in place of the simple $\mathrm{r}^{2}$ or partial $\mathrm{r}^{2}$ in the formula. The test statistics has a $\chi^{2}$ distribution with $d . f . k$. The L-M test like Wald test has a $\chi^{2}$-distribution with $d . f . r$. if the test statistics is significant at the level, rejecting the hypothesis of coefficient stability (Maddala, 2001, pp. 176-177). Three, to give some idea about White's heteroscedasticity corrected standard errors, the variances of $\hat{\beta}$ of $k$ variable regression model with the variance of any partial coefficient is obtained as:

$$
\operatorname{var}\left(\hat{\beta}_{i}\right)=\frac{\sum \hat{w}_{i i}^{2} \hat{u}_{i}^{2}}{\left(\sum \hat{w}^{2}{ }_{j i}\right)^{2}}
$$

Since $\hat{u}^{2}{ }_{i}$ are not directly observable, White suggests the squared residual for each $i$. Where, $\hat{u}_{i}$ are the residuals obtained from the $k$ variable regression (Gujarati, 2012, pp. 439-440). Four, as the post estimation techniques, the CUSUM and CUSUMSQ tests are to be applied to obtain whether the data set have structurally broken or not. In general, the CUSUM (cumulative sum) and CUSUMSQ (CUSUM squared) tests can be used to test the constancy of the coefficients in a model. It is shown that the conventional CUSUM test for structural change can be applied to cointegrating regression residuals leading to a consistent residual-based test for the null hypothesis of cointegration. The tests are semi-parametric and utilize fully modified residuals to correct for endogeneity and serial correlation and to scale out nuisance parameters. By applying these tests in the data series, the results will be more reliable and robust. Among many other investment affecting factors, only systematically affecting stochastic variables have been considered in this paper for econometric estimation.

\section{Challenges For Domestic Investment In Bangladesh}

Domestic investment in Bangladesh is stimulated by real GDP growth as well as expansion of exports of goods and services. In addition, the development level of financial sector and human capital is also crucial for stimulating domestic investment in the long term whereas the increase in domestic credit availability will enhance domestic investment in the short run. The domestic investment in Bangladesh is facing with the following challenges:

7.1 The Macroeconomic Instability: The macroeconomic instability refers to the phenomena that make the domestic macroeconomic environment less predictable and it can take the form of volatility of key macroeconomic variables or of un-sustainability in their behavior. The weak macroeconomic stability is shown by the following Table: Table 7.1.1 indicates that Bangladesh has achieved improvement in every field of macroeconomic factors but nothing has happened yet as expected that provides a poor macroeconomic stability here. The failure on the part of Bangladesh to keep up with the growth in other countries thus points to the need to improve its investment climate.

Table 7.1.1: Human Development Progress in Bangladesh

\begin{tabular}{|l|l|l|l|l|l|}
\hline Major Macroeconomic Factors & 1980 & 1990 & 2000 & 2010 & 2011 \\
\hline Human Development Index & 0.259 & 0.313 & 0.390 & 0.469 & - \\
\hline Population below National Poverty Line (\%) & - & 58.8 & 49.8 & 40.0 & 31.50 \\
\hline Fertility Rate (birth per woman) & 5.0 & 4.3 & 3.0 & 2.2 & 2.11 \\
\hline Infant Mortality Rate (per thousand people) & 101.4 & 94.0 & 66.3 & 43.0 & 35.0 \\
\hline Life Expectancy at birth (years) & 56.9 & 56.0 & 60.6 & 66.9 & 69.0 \\
\hline Gross Primary Enrollment Ratio (\%) & 61.0 & 72.0 & 97.5 & 93.8 & 114.20 \\
\hline Gross Secondary Enrollment Ratio (\%) & 18.0 & 19.0 & 42.0 & 44.1 & 50.80 \\
\hline Adult Literacy Rate (age 15 and older (\%)) & 29.0 & 35.0 & 45.0 & 55.0 & 58.79 \\
\hline
\end{tabular}

Source: UNDP, Human Development Report (2013).

7.2 Expectation Variability regarding the (Future) Profitability of Current Investment: With other things equal, business is more inclined to increase investment spending in boom periods than in bust periods. This factor is mostly present in Bangladesh that indicates the negative sides of domestic investment. That is, the expected earning capacity of profit is very low in Bangladesh; resulting is the low level of domestic investment.

7.3 The High Level of Depreciation Allowances (DEP) Available to A Company: Typically, the allowances are based on the initial cost of the assets minus any projected salvage value. The less depreciation allowances raise the country's domestic investment. But, it is not favourable for investment in Bangladesh.

7.4 The Volatility of the Stock Market: Capitals for local investment are accumulated through this market. The stock market in Bangladesh is very much volatile. The trading in this market has become a very risky job for the small investors. As losing capital from this market, people are not interested to further investment in the market. It has also direct effect on the investment of other sectors. 
7.5 Access to Finance: The private sector in Bangladesh gets reasonable access to finance. Between July 2009 and June 2010 (FY2009-10), credit to the private sector increased by 21.1 percent while credit to the public sector increased by 9.4 percent. This is in sharp contrast with credit flows in FY2008-09 when credit to the private sector increased by 14.6 percent and credit to the public sector rose by as much as 20.3 percent (Bangladesh Bank, 2011).

7.6 Low Level of Savings Rate: Saving is one of the major components of domestic investment. The more savings rate, the more the capital formation, the more domestic investment is the macroeconomic theory. There is always a big gap remained for many years between national savings and investment in Bangladesh. In Bangladesh the saving rate is very low and it stands to 23.47 percent of GDP in 2013-14, the investment is thus very low at 28.69 percent.

7.7 The Volatility of the Exchange Rate: An exchange rate is regarded as the value of one country's currency in terms of another currency. It affects the relative prices of foreign goods which increase the overall purchasing power of business income. Unfortunately, the exchange rate in Bangladesh is very much volatile for which investment figure is also be hampered.

7.8 The Low Productive Capacity of Labour: Productive capacity per worker can be increased by longer hours, more effort, or improved skills on the part of the labour force, or by more capital equipment, improved technology, or better management. The productive capacity of Bangladesh is any how very low and the labour productivity is 1: 3 compare to the US labour. This is why; the investment in Bangladesh is very poor.

7.9 High Rate of Interest: Interest of a country is one of the major factors for domestic investment. The low interest rate is the high investment. In Bangladesh the interest rate is very high as well as the variations are remained in the interest rate of different banks and financing institutions resulting is the low investment in the country.

7.10 The Extent of Government Deficit: The extent to which government deficits create a "crowd out" problem i.e., government borrowing which divert savings that would otherwise be borrowed by businesses to purchase new plant and equipment into government hands, that reduces the level of private investment.

7.11 Governance Issues: Good governance is critical for the investment climate and key to long run economic growth. Bangladesh has some positive achievements in the sphere of governance but instances of governance failures on economic, political and institutional fronts are overwhelmingly large, which vitiate the overall investment environment and threaten the process of investment and economic growth. Economic Ground: governance difficulties are observed in inefficient public spending, high losses of public sector enterprises (PSEs), power sector thefts, and the default culture in the banking system. A comprehensive solution of the corruption problem in banking, power sector, and PSEs would require privatization along with improvements in the regulatory capacity of the public sector.But, sadly enough, the process of privatization has been largely halted. Political Ground: Hartals, terrorism and extortion, often perpetrated under political patronage, are major obstacles to expansion of business, which damage the country's image abroad. To the average citizen, the most pressing governance problem is the weak law and order situation, which threatens to erode people's confidence in the law-enforcing agencies (Ahmed, 2001). Institutional Frame: World Bank reports reveal glaring institutional weaknesses and corruption in civil service, public audit and accounts, the law and order institutions, and the judiciary. Reports of the Transparency International also corroborate the World Bank's findings.

7.12 The Poor Economic Infrastructure: Economic infrastructure improves business efficiency through increased connectivity, supports economies of scale, increases labour market flexibility and opens up new markets. The domestic investment is hampered in Bangladesh due to the poor pattern of country's economic infrastructures.

\subsubsection{Result of the Chow Test and the Coppock Instability Index}

The Chow test is conducted to measure the structural changes in the aggregate domestic investment in Bangladesh. It is the pre-estimation method of checking model stability.

Table 8.1.1: Results of the Chow Test \& Coppock Instability Index (CII)

\begin{tabular}{|l|l|l|l|l|l|}
\hline Chow Breakpoint Test:1990 & 14.19 & Prob: F(2,42) & 0.00 & Pre-Liberalization Period (Before 1990) & 16.5 \\
\hline F- Statistic & 63.60 & Prob: Chi-square (2) & 0.00 & $\begin{array}{l}\text { Post Liberalization Period (After 1990) } \\
\text { Over all }\end{array}$ & 14.9 \\
\hline Log Likelihood Ratio & & & & The Chow Test is performed with Eviews 5.1 \\
\hline
\end{tabular}

Table 8.1.1 shows the results that the calculated F-statistic (14.19) is greater than the F-critical value and it is also confirmed by the p-value equals to 0.0000 which is lower than any significance levels $(\alpha)$. This 
indicates that the null hypothesis is significant and there is no structural breakpoint of domestic investment in Bangladesh in 1990.The year 1990 was politically important for Bangladesh because it turned into the democracy after a long struggle against military autocracy. The investment pace was yet remain almost same. Hence, there is no structural breaking point of domestic investment in 1990 in Bangladesh.The higher value of the Coppock Instability Index indicates the higher degree of instability. The CII is 16.5 percent during the preliberalization regime and 14.9 percent during the post-liberalization regime. Therefore, the instability in domestic investment is higher during pre-liberalization than post-liberalization periods. It is also higher than that of the overall study period (13.7 percent).

\subsubsection{Descriptive Statistics of Domestic Investment Function}

Descriptive statistics of the function indicates that the mean-to-median ratio of each variable is approximately one. The standard deviation is also low compared to the mean, showing a small coefficient of variation except FDI. The range of variation between maximum and minimum is also reasonable. The numeric of skewness of each variable is low and is mildly negatively skewed but for human capital and domestic credit availability is positively skewed. The figure for kurtosis in each variable is below 3 lndi and lngrgdp which confirms near normality. The Jarque-Bera test statistic also accepts the null hypothesis of normal distribution of each variable, except lndiand lngrgdp.But, these two have also been normal at the first difference, with varying probabilities. The Sum and Sum Sq. Dev. ensures that there is no structural break of the data.

\subsubsection{Correlation among the Variables of Domestic Investment Function}

The correlation matrix explains the correlations among the variables of the function. It shows that the dependent variable lndi is positively related with all of the independent variables of the function as expected. It is also consistent with the theory of domestic investment that it is the positive functions of GDP growth rate, financial intermediation, real export, human capital, domestic credit availability but negatively related with the foreign direct investment. The matrix shows that FDI is also positively related with the domestic investment function. It may be due to insignificant contribution to the domestic economy of Bangladesh.

\subsection{Results of Unit Root Tests of the Domestic Investment Function}

The Augmented Dickey-Fuller test, the D-F (GLS) test and the Phillips-Perron testhave been applied for testing unit root problem. The results of these tests are as follows:

Table 8.2.1: Results of ADF, D-F (GLS) and Phillips Perron Unit Root Tests

\begin{tabular}{|c|c|c|c|c|c|c|c|c|c|c|}
\hline \multirow[b]{2}{*}{$\begin{array}{l}\frac{0}{0} \\
\frac{\pi}{\pi} \\
\frac{\pi}{\pi} \\
>\end{array}$} & & \multicolumn{4}{|c|}{ With An Intercept But Not A Trend } & \multicolumn{5}{|c|}{ With An Intercept and A Linear Trend } \\
\hline & $\begin{array}{l}\text { ADF } \\
\text { Stat. }\end{array}$ & $\begin{array}{l}\text { D-F } \\
\text { (GLS) } \\
\text { Stat. }\end{array}$ & P-P Stat. & $\begin{array}{l}\text { Crit. Val. } \\
(1 \%)\end{array}$ & $\begin{array}{l}\text { Crit. Val. } \\
(5 \%)\end{array}$ & $\begin{array}{l}\text { ADF } \\
\text { Statistic }\end{array}$ & $\begin{array}{l}\text { D- } \\
\text { F(GLS) } \\
\text { Stat. }\end{array}$ & P-P Stat. & $\begin{array}{l}\text { Crit.Val. } \\
(1 \%)\end{array}$ & $\begin{array}{l}\text { Crit.Val } \\
.(5 \%)\end{array}$ \\
\hline lndi & -3.5544 & -0.5067 & -3.9678 & -2.6225 & -2.9350 & -4.7443 & -2.4657 & -4.9422 & $\begin{array}{l}-3.7700 \\
\end{array}$ & -3.5236 \\
\hline lngrgdp & -1.0667 & -1.5246 & $\begin{array}{l}-6.8190 \\
\end{array}$ & -2.6241 & -2.9434 & -4.0975 & -7.0924 & -11.4151 & -3.7700 & -3.5403 \\
\hline $\operatorname{lnfdi}$ & -1.4742 & -2.1723 & $\begin{array}{l}-3.0970 \\
\end{array}$ & -2.6226 & -2.9389 & -3.8793 & -3.7664 & -3.9603 & -3.7700 & -3.5236 \\
\hline $\operatorname{lnfi}$ & -0.9445 & 0.2228 & -1.2216 & -2.6226 & -2.9369 & -4.4418 & -4.3696 & -4.446 & -3.7700 & -3.5236 \\
\hline $\ln r x$ & -0.8492 & -0.6617 & -0.4197 & -2.6226 & -2.9350 & -3.7294 & -3.2140 & -3.6227 & -3.7700 & -3.5236 \\
\hline $\operatorname{lnh} c$ & -0.4335 & -0.3979 & -0.4698 & -2.6226 & -2.9350 & -1.8472 & -1.6730 & -1.8797 & -3.7700 & -3.5236 \\
\hline lncr & -1.4580 & 0.0680 & -1.4580 & -2.6226 & -2.9350 & -3.4561 & -3.2167 & -3.5281 & -3.7700 & -3.5236 \\
\hline$\Delta \ln d i$ & $\begin{array}{l}-7.7488 \\
\end{array}$ & -2.5121 & -10.7942 & -2.6241 & -2.9390 & -9.0594 & -4.685 & -17.5229 & $\begin{array}{l}-3.7700 \\
\end{array}$ & $\begin{array}{l}-3.5298 \\
\end{array}$ \\
\hline$\Delta$ lngrgdp & -10.904 & -3.2668 & -49.3116 & -2.6256 & -2.9390 & -10.742 & -9.8987 & -53.2653 & -3.7700 & -3.5298 \\
\hline$\Delta \operatorname{lnfdi}$ & -7.1732 & -5.7236 & -9.1768 & -2.6241 & -2.9390 & -7.0736 & -7.3180 & -9.0325 & -3.7700 & -3.5298 \\
\hline$\Delta \operatorname{lnfi}$ & -7.7819 & -7.7781 & -10.4265 & -2.6241 & -2.9390 & -7.6469 & -6.8940 & -11.0649 & -3.7700 & -3.5298 \\
\hline$\Delta \ln r x$ & -7.1390 & -6.8220 & -8.6033 & -2.6256 & -2.9390 & -6.9810 & -7.1419 & -8.8178 & -3.7700 & -3.5298 \\
\hline$\Delta \operatorname{lnhc}$ & -6.0185 & -6.0970 & -6.0185 & -2.6241 & -2.9370 & -6.1025 & -6.2254 & -6.1029 & -3.7700 & -3.5266 \\
\hline$\Delta \operatorname{lncr}$ & -8.4000 & -5.2120 & -7.8333 & -2.6241 & $\begin{array}{l}-2.9390 \\
\end{array}$ & -8.2663 & -6.6551 & -8.1324 & -3.7700 & -3.5298 \\
\hline
\end{tabular}

The test is conducted with Eviews 5.1.

Note: $95 \%$ critical value for the Augmented Dickey - Fuller statistic=-2.9665.

* Critical values (5\%) are from Mackinnon (1991). $\Delta=$ First Difference,

** Critical values (1\%) are from Mackinnon (1991).

Table 8.2.1 indicates the level values are reported as non-stationary because the calculated values are lesser than their critical values in absolute term. The null hypothesis could not be rejected then. Table further indicates that the non-stationarity problem has been vanished after the first difference of the data; because the ADF, D-F and P-P tests statistics are greater than their critical values at $1 \%$ and $5 \%$ level of significance and the null hypothesis of non-stationarity are rejected and the data have been stationary after the first difference. The correlogram test has also justified and supported the results. Therefore, the null hypothesizes of unit root problems have been accepted and the data series suffers with a unit root problem at their level form. But, the 
problems have been vanished after the first difference because the null hypothesizes have been rejected then and the data becomes stationary for the integration of order one $I(1)$.

\subsection{Result of the Cointegration Test of the Domestic Investment Function}

Since the variables of the function are integrated of order 1 (one), it confirms the possibility of cointegration between them. The estimated results of cointegration tests are presented in the following Table.

Table 8.3.1: Cointegration Results of the Domestic Investment Function

\begin{tabular}{|c|c|c|c|c|c|c|c|c|c|}
\hline \multicolumn{10}{|c|}{ Cointegration between Domestic Investment and GDP Growth Rate } \\
\hline$H_{0}$ & $H_{A}$ & $\begin{array}{l}\text { Eigen } \\
\text { Value }\end{array}$ & $\begin{array}{l}\text { Trace } \\
\text { Statistic }\end{array}$ & $\begin{array}{l}5 \% \text { Crit. } \\
\text { Value }\end{array}$ & $\begin{array}{l}\text { Probabilit } \\
y^{* *}\end{array}$ & $\begin{array}{l}\text { Max-eigen } \\
\text { Value }\end{array}$ & $\begin{array}{l}5 \% \text { Crit. } \\
\text { Value }\end{array}$ & $\begin{array}{l}\text { Probabil } \\
\text { ity** }\end{array}$ & Hypothesis \\
\hline $\mathrm{r}=0$ & $\mathrm{r}=1$ & 0.724429 & 77.3822 & 15.49471 & 0.0000 & 50.26754 & 14.26460 & 0.0000 & None* \\
\hline $\mathrm{r}<=1$ & $\mathrm{r}=2$ & 0.501049 & 27.1146 & 3.841466 & 0.0000 & 27.11468 & 3.841466 & 0.0000 & Atmost $1^{*}$ \\
\hline \multicolumn{10}{|c|}{ Cointegration between Domestic Investment and FDI } \\
\hline $\mathrm{r}=0$ & $\mathrm{r}=1$ & 0.633328 & 73.74490 & 15.49471 & 0.0000 & 39.12825 & 14.26460 & 0.0000 & None* \\
\hline $\mathrm{r}<=1$ & $\mathrm{r}=2$ & 0.588360 & 34.61665 & 3.841466 & 0.0000 & 34.61665 & 3.841466 & 0.0000 & Atmost $1^{*}$ \\
\hline \multicolumn{10}{|c|}{ Cointegration between Domestic Investment and Financial Intermediation } \\
\hline $\mathrm{r}=0$ & $\mathrm{r}=1$ & 0.625056 & 55.18462 & 15.49471 & 0.0000 & 38.25816 & 14.26460 & 0.0000 & None* \\
\hline $\mathrm{r}<=1$ & $\mathrm{r}=2$ & 0.352095 & 16.92646 & 3.841466 & 0.0000 & 16.92646 & 3.841466 & 0.0000 & Atmost $1^{*}$ \\
\hline \multicolumn{10}{|c|}{ Cointegration between Domestic Investment and Real Export } \\
\hline $\mathrm{r}=0$ & $\mathrm{r}=1$ & 0.767632 & 77.81492 & 15.49471 & 0.0000 & 56.91784 & 14.26460 & 0.0004 & None* \\
\hline $\mathrm{r}<=1$ & $\mathrm{r}=2$ & 0.414812 & 20.89707 & 3.841466 & 0.0000 & 20.89707 & 3.84147 & 0.0000 & Atmost $1^{*}$ \\
\hline \multicolumn{10}{|c|}{ Cointegration between Domestic Investment and Human Capital } \\
\hline $\mathrm{r}=0$ & $\mathrm{r}=1$ & 0.631326 & 53.8609 & 15.4947 & 0.0000 & 38.91587 & 14.26460 & 0.0000 & None* \\
\hline $\mathrm{r}<=1$ & $\mathrm{r}=2$ & 0.318329 & 14.94511 & 3.84146 & 0.0001 & 14.94511 & 3.841466 & 0.0001 & Atmost $1^{*}$ \\
\hline \multicolumn{10}{|c|}{ Cointegration between Domestic Investment and Domestic Credit Availability } \\
\hline $\mathrm{r}=0$ & $\mathrm{r}=1$ & 0.598644 & 51.30743 & 15.49471 & 0.0000 & 35.60332 & 14.26460 & 0.0000 & None* \\
\hline $\mathrm{r}<=1$ & $\mathrm{r}=2$ & 0.331467 & 15.70411 & 3.841466 & 0.0001 & 15.70411 & 3.841466 & 0.0001 & Atmost $1 *$ \\
\hline
\end{tabular}

Table 8.3.1 shows that the trace and max-eigen value statistics for domestic investment and GDP growth rate are 77.38 and 50.27 for the null hypothesis $r=0$; both the values are greater than the critical values of 15.49 and 14.26 at $5 \%$ ( with 0.00 probability) levels of significance in the first row. Thus, the null hypothesis of no cointegration is rejected and the alternative hypothesis is accepted at 5 percent significance level. In the second row of the table, the values of trace and max-eigen value both are greater than their critical values at $5 \%$ (with 0.0000 probability) significance level. Hence, the null hypothesis of no cointegration is also rejected. Therefore, there are 2 (two) cointegrating stable relations between domestic investment and GDP growth rate. Results also show that the null hypothesis of at most two cointegrating vectors $\left(\mathrm{H}_{0}: \mathrm{r}<=0\right.$ and $\mathrm{H}_{0}$ : $\mathrm{r}$ $<=1)$ is rejected at 5\% level of significance, according to both the trace and max-eigen value statistics. Same results have been found for domestic investment and its residual components. Thus, there are 2 (two) cointegrating stable relationships between domestic investment and its various components in Bangladesh and they all are converging each other in the longrun.

\subsection{Estimation of the Domestic Investment Function}

Since all variables are cointegrated each other, the function follows the properties of ordinary least squares (OLS) method. It is therefore, very much convenient to estimate the domestic investment function (6.2.1) with the OLS method. In this case, the software Eviews-5.1 has been conducted. The estimated regression equation is:

$$
\begin{aligned}
& \Delta \ln d i=0.018854+0.038227 \Delta \ln g r g d p+0.007096 \Delta \ln f d i-0.000601 \Delta \ln f i+0.260025 * * \\
& \Delta \ln r x-0.020120 \Delta \ln h c+0.318036 * \Delta \ln c r \ldots \ldots \ldots \ldots \ldots \ldots \ldots \ldots \ldots \ldots \ldots \ldots \ldots \ldots \ldots \ldots \ldots \ldots \ldots \ldots \ldots \ldots \ldots \ldots \ldots \ldots \ldots \ldots \ldots
\end{aligned}
$$

Note: The estimation is done with the OLS method and is conducted with Eviews 5.1.

* Coefficient is significant at 0.05 levels of significance. $* *$ Coefficient is significant at 0.01 levels.

The estimated coefficients of the domestic investment equation (8.4.1) show that domestic investment in Bangladesh is positively influenced by GDP growth rate, foreign direct investment, real export and domestic credit availability of which real export and domestic credit are significant. Domestic investment again negatively influenced by financial intermediation and human capital but they are insignificant. FDI on the other hand, affects domestic investment positively which contradicts with the theory. This may be due to insignificant contribution to the domestic economy of Bangladesh. 
The Wald test of domestic investment function confirms that the coefficients are jointly insignificant because the probabilities are greater than the significance level $(\alpha=0.05,0.01)$ for both F-statistic and Chi-square test. But, individually, some variables may be significant for domestic investment in Bangladesh.

\subsection{Result of Vector Error Correction Modeling (VECM)}

Error correction model between domestic investment and its various components is used to show the short run dynamics to the long run equilibrium of the function. The VECM results indicate that long run causalities are exist between GDP growth rate, financial intermediation, real exports, human capital and domestic credit to the domestic investment in Bangladesh.On the other hand FDI, financial intermediation and domestic credit availability are negatively and others are positively related in the long run. The short run effects exist between domestic investment and financial intermediation. The ECM term of all independent variables is significant that indicates the long term causations go to the domestic investment in Bangladesh from these factors and there are significant scopes for short run dynamic adjustment to the long run equilibrium among them.

\subsection{Results of Vector Autoregression (VAR) Model}

According to the theory of elasticity, the coefficient of the cointegrating equation with log value and the coefficients of the respective first difference value of the independent variable are known as long and short run elasticity of the function respectively.

Table 8.6.1: Long and Shortrun Elasticities of the Domestic Investment Function

\begin{tabular}{|l|l|l|l|l|l|l|l|}
\hline Elasticity & Constant & $\Delta$ lngrgdp & $\Delta$ lnfdi & $\Delta \operatorname{lnfi}$ & $\Delta \operatorname{lnrx}$ & $\Delta \operatorname{lnhc}$ & $\Delta \operatorname{lncr}$ \\
\hline Long-term & 0.018854 & 0.038227 & 0.007096 & -0.000601 & $0.260025^{*}$ & -0.020120 & $0.318036^{*}$ \\
& 0.019354 & 0.029153 & 0.010561 & 0.004752 & {$[0.092429]$} & 0.136432 & 0.162744 \\
& {$[0.974191]$} & {$[1.311263]$} & {$[0.671908]$} & {$[-0.126408]$} & 2.813244 & {$[-0.147475]$} & {$[1.954211]$} \\
\hline Short-term & 0.001587 & $1.404694^{* *}$ & $-0.209856^{* *}$ & $0.020526^{*}$ & -0.001359 & -0.274968 & 0.376160 \\
& $(0.00754)$ & $(0.18436)$ & $(0.02349)$ & $(0.00722)$ & $(0.26915)$ & $(0.20410)$ & $(0.33762)$ \\
& {$[0.21064]$} & {$[7.61929]$} & {$[-8.93396]$} & {$[2.84112]$} & {$[-0.00505]$} & {$[-1.34720]$} & {$[1.11414]$} \\
\hline
\end{tabular}

The test is performed with Eviews 5.1.

Note: Estimated with VAR method of the domestic investment function.

** Statistically significant at 1 percent level of significance. * Significant at 5 percent level.

The standard error is shown in the bracket and the t-statistics are shown by the parenthesis.

The first row of the Table 8.6.1 indicates the long run elasticities of the domestic investment function because it contains the coefficients of the log values of the estimated function. The coefficients of real exports and domestic credit availability are significant at 0.05 levels of significance. This means that an increase in real export and domestic credit may increase the domestic investment growth by 26 and 32 percent respectively in the long run. The coefficient of FDI is also positive; it is due to very negligible contribution to the domestic investment. Table also shows that the coefficients of the GDP growth rate, FDI and financial intermediations are statistically significant in the short run both at 1 and 5 percent level of significance. The coefficients of real exports and human capital are negatively related whereas, the coefficient of constant term, GDP growth rate, financial intermediation and domestic credit are positively elastic to domestic investment in Bangladesh in the short run.

\subsection{Result of Granger Causality Test}

Table 8.7.1: Pair-wise Results of Granger Causality Test of the Function

\begin{tabular}{|c|c|c|c|c|c|}
\hline Null Hypothesis & Obs. & Lag & F-Statistic & Probability & Decisions \\
\hline $\begin{array}{l}\Delta \operatorname{lngrgd} d p \text { does not Granger Cause } \Delta \ln d i \\
\Delta \operatorname{lndidoes} \text { not Granger Cause } \Delta \operatorname{lngrg} d p\end{array}$ & 39 & 2 & $\begin{array}{l}8.87487 \\
0.70899\end{array}$ & $\begin{array}{l}0.00079 \\
0.49927\end{array}$ & $\begin{array}{l}\text { Rejected** } \\
\text { Accepted }\end{array}$ \\
\hline $\begin{array}{l}\Delta \ln f d i \text { does not Granger Cause } \Delta \ln d i \\
\Delta l n d i \text { does not Granger Cause } \Delta \ln f d i\end{array}$ & 34 & 7 & $\begin{array}{l}1.72805 \\
2.54819\end{array}$ & $\begin{array}{l}0.16204 \\
0.04968\end{array}$ & $\begin{array}{l}\text { Accepted } \\
\text { Rejected* }\end{array}$ \\
\hline $\begin{array}{l}\Delta \ln f i \text { does not Granger Cause } \Delta \ln d i \\
\Delta \ln d i \text { does not Granger Cause } \Delta \ln f i\end{array}$ & 39 & 1 & $\begin{array}{l}3.21610 \\
1.76622 \\
\end{array}$ & $\begin{array}{l}0.08088 \\
0.19178 \\
\end{array}$ & $\begin{array}{l}\text { Rejected* } \\
\text { Accepted }\end{array}$ \\
\hline $\begin{array}{l}\Delta \ln r x \text { does not Granger Cause } \Delta \ln d i \\
\Delta \ln d i \text { does not Granger Cause } \Delta \ln r x\end{array}$ & 39 & 2 & $\begin{array}{l}4.19845 \\
7.76382\end{array}$ & $\begin{array}{l}0.02347 \\
0.00167\end{array}$ & $\begin{array}{l}\text { Rejected* } \\
\text { Rejected** }\end{array}$ \\
\hline $\begin{array}{l}\Delta \operatorname{lnh} c \text { does not Granger Cause } \Delta \ln d i \\
\Delta \ln d i \text { does not Granger Cause } \Delta \ln h c\end{array}$ & 28 & 13 & $\begin{array}{l}19.2057 \\
129.725\end{array}$ & $\begin{array}{l}0.17695 \\
0.06863\end{array}$ & $\begin{array}{l}\text { Accepted } \\
\text { Rejected* }\end{array}$ \\
\hline $\begin{array}{l}\Delta l n h c r \text { does not Granger Cause } \Delta l n d i \\
\Delta l n d i \text { does not Granger Cause } \Delta l n h c r\end{array}$ & 39 & 2 & $\begin{array}{l}2.48392 \\
8.02345\end{array}$ & $\begin{array}{l}0.09843 \\
0.00140\end{array}$ & $\begin{array}{l}\text { Rejected* } \\
\text { Rejected** }\end{array}$ \\
\hline
\end{tabular}

The test is performed with the software Eviews 5.1.

Note: * Denotes the rejection of the null hypothesis at 0.05 levels.

$* *$ Denotes the rejection of the null hypothesis at 0.01 levels.

Granger Causality theorem (1988) mentions that there should be at least one direction of causality remained between two variables, if they are cointegrated in the same order. The causality model has been tested by F- statistics using different lags. Results show that the null hypothesis of GDP growth rate does not cause domestic investment is rejected at 0.01 percent and the alternative hypothesis is accepted indicated by the first 
row. Thus, it can be said that GDP growth rate leads domestic investment in Bangladesh to grow. Since, F statistic is insignificant indicated by the $2^{\text {nd }}$ line of the first row, the null hypothesis that domestic investment does not cause GDP growth rate is accepted. That is, domestic investment in Bangladesh does not lead GDP growth rate to grow in the short run.Results show that real export and domestic investment as well as domestic credit and domestic investment both are significant for each other.Hence, there are bidirectional causalities between real export and domestic credit availability to domestic investment in Bangladesh because they cause each other to grow at the same tandem.On the other hand, there exist unidirectional causality between GDP growth rate, FDI, financial intermediation and human capital to domestic investment in Bangladesh in the short run.

\subsection{Impulse Response Analysis of the Function in the VAR Model}

The response of domestic investment to other variables is correlated and strongly convergent which is depicted by the following Figures:

Figure 8.8.1: Result of Impulse Responses Analysis of the Function
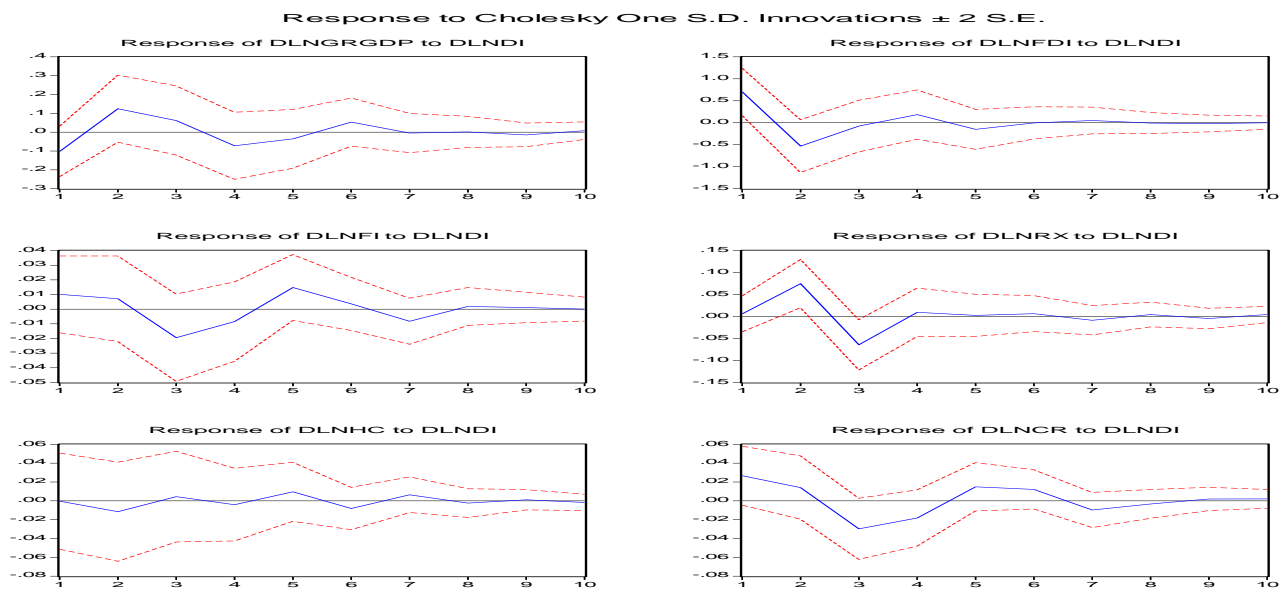

*For researcher's convenience only 10 subsequent periods have been considered.

Figure 8.8.1 presents the impulse response of the domestic investment to the GDP growth rate and other variables of domestic investment function in the Bangladesh context for the post-independent era. The response of FDI to domestic investment reveals that it was only favourable in the first and fourth period but negative in all other periods. Thus, this has a bad implication on the performances of Bangladesh economy. Likewise, GDP growth rate has negative effect on domestic investment in the first and fourth period but increases henceforth. Indeed, financial intermediation and real exports have bad effects in the third period but have overall steady positive effect on domestic investment. Human capital has slow negative but steady effect whereas, domestic credit has negative effect on domestic investment but it is converging with domestic investment over the period.Therefore, the response of all variables is either positive or negative in the short run but in the long run they all are responded towards the domestic investment in Bangladesh.

\subsection{Result of Variance Decompositions of the Function}

The variance decomposition outputs are reported that the variance of domestic investment is always caused by 100 percent by itself in the first year. In the second year, it is decomposed into its own variance (68.71\%) followed by GDP growth rate (20.31\%), FDI (4.72\%), financial intermediation (4.53\%), real exports $(0.38 \%)$, human capital $(0.50 \%)$ and domestic credit availability $(0.86 \%)$. However, in subsequent years, the share of domestic investment decline to approximately $57.58 \%$ followed by the volume of FDI, GDP growth rate, financial intermediation, real export, human capital and volume of domestic credit availability are increased to $(7.52 \%, 18.45 \%, 4.05 \%, 5.23 \%, 4.22 \%$ and $2.94 \%$ respectively). The volatility of domestic investment is mainly caused by its own variation, as it always accounts for major portion (above $50 \%$ ) of the fluctuations.

IX. Model Diagnostics of the Domestic Investment Function 9.1 Results of Autocorrelation and Heteroscedasticity Test

Table 9.1.1: Results of L-M, B-G and WGH Tests

\begin{tabular}{|l|l|l|l|l|l|l|}
\hline \multirow{2}{*}{ Tests } & \multicolumn{2}{|l|}{ Lagrange Multiplier Test } & \multicolumn{3}{l|}{ White General Heteroscedasticity Test } \\
\cline { 2 - 7 } & L-M Test Stat. & Probability & Conclusions & WGH Stat. & Probability & Conclusions \\
\hline F-statistic & 1.339529 & 0.276263 & No Autocorrelation & 2.494750 & 0.022704 & No Heteroscedasticity \\
\hline Obs*R-squared & 3.167369 & 0.205218 & Normally Distributed & 21.18537 & 0.047731 & Normally Distributed \\
\hline
\end{tabular}


Results show that in case of equation (8.4.1), both the probability values are greater than 0.05 . The Fstatistic of the L-M test is 1.34 and the probability is 0.28 which greater than 0.05 . That is, the null hypothesis of autocorrelation is rejected. Likewise, Breusch-Godfrey serial correlation test reveals no autocorrelation among the variables (Obs*R-squared 3.16769 with associated P-value 0.205). These imply that the estimated domestic investment equation does not suffer from autocorrelation problem as well as the residuals follow the normality of the distribution. The F-statistic of the White General Heteroscedasticy test on the other hand is 2.49 with corresponding probability 0.023 which is less than the critical value $(\alpha) 0.05$. This also implies that the null hypothesis of no heteroscedasticity is accepted.That is, the equation (8.4.1) is free from heteroscedasticity problem. The Breusch-Pagan-Godfrey test also reveals of the normal distribution.

\subsection{Results of the Stability Test}

The plots of CUSUM test show that the statistic stays within the 95 percent confidence interval that is, there is no structural break of the model over the period. On the other hand, the plots of the CUSUMSQtest indicate that the statistics begins from outside of the confidence interval but very soon it remains inside of the 95 percent confidence interval. These imply that estimates and the variation of the estimates of the model are stable over the period. Thus, no structural change is found in the model. Finally, it could be concluded that the modelis structurally stable and specified.

\section{Policy Implications}

The estimated coefficients of the domestic investment equation (8.4.1) show that the coefficient of GDP growth rate is positive as expected but it is low elastic to the domestic investment. The coefficients of FDI, real exports and domestic credit are positively related to domestic investment as expected of which the coefficient of real exports is significant at 0.01 levels. The coefficients of financial intermediation and human capital are negative as expected to domestic investment but they are not significant. Domestic investment of Bangladesh is however influenced by all of its factors but financial intermediation and human capital have the negative impact on it. In contrast, GDP growth rate, FDI, real export and domestic credit have the positive impact on the domestic investment of Bangladesh of which real export and domestic credit have significant impact. Theory states that the key factor behind a country's economic success is the upsurge in its local business entrepreneurship; and the priority should be given to the domestic investors to lead the industrial upsurge. A significant portion of this domestic investment should come not only from the urban areas but also from the rural areas. Although most of the people in Bangladesh live in the rural areas, there is a lack of job opportunities there. So, poor rural savings does not play a significant role in making capital for industrialization in Bangladesh.The most notable change in the last 15 years is that the business entrepreneurs in Bangladesh are now more confident. Bangladesh has a huge pool of highly educated and skilled human resources and now the question is how to leverage that. It is now more important to leverage education than cheap labour so that it could emphasis first on domestic investment. Bangladesh's economy witnessed a somewhat positive growth in 2014, but still far from the robustness required to become a middle-income country by 2021 . The country now needs a lot more resources to invest in physical infrastructure as well as for the development of power and gas sectors, which are among the major causes of the sluggish private investment in the country.

\section{Policy Recommendations}

On the basis of the findings, the following policies should be adopted for stimulating domestic investment in Bangladesh:

- The govt. should implement appropriate policies to ensure macroeconomic stability with increasing GDP in a sustained manner, foster growth promoting and growth accommodating policies;

- Individual and national savings should be increased for domestic capital formation that may reduce the dependency on FDI in Bangladesh;

- Govt. should further peruse the effort for domestic capital formation by strengthening public and private saving mobilization;

- The interest rate of banks and other financial institutions should be rationally reduced and labeled;

-The volatility of the stock market should be minimized, stabled and efficiently regulated;

- The financial institutions of Bangladesh should be efficient and profession for the easy access to finance and credit availability for domestic investors;

- The Motivation for the high Expectation Regarding the (Future) Profitability of Current Investment should be conducted; because the more expected level of earning profit by the firm is the more level of domestic investment.

- Policies should be adopted to enhance productivity of human capital by implementing education, training, technological knowhow and other factors of human capital.

- Wage rate in Bangladesh should be rationalized so that labourer can have a minimum guarantee of maintaining their livelihoods. 
- Investment friendly atmosphere with good governance (political, economic and infrastructure) should be ensured.

- Strengthening government institutions and the rule of law will do much to improve the climate for investment, productivity and growth;

- The govt. should eagerly address the problem of power and energy crisis as well as to reduce the system loss problem in this regard.

- The economic infrastructure of Bangladesh should be developed so that business efficiency is improved through increasing connectivity, supporting economies of scale, increasing labour market flexibility and opening up new markets;

- Corruption is a major constraint and an obstacle to private domestic investment in Bangladesh. So it should be controlled and checked;

- The sustainable democratic Political Atmosphere in Bangladesh should be ensured for increasing the worthiness of the investors; and

\section{Conclusion}

The objective of this chapter is to estimate the domestic investment function in order to assess the influence of the factors of domestic investment as well as to examine the causal relationships associated with them in Bangladesh. In this context, the trend of the variables and the applied pre-estimation techniques show that all the variables have the long run upward slopes, there is no structural breakpoint in 1990 in the data series of domestic investment; the data series are more instable during the pre-liberalization periods; the variables are positively correlated with domestic investment and finally, the data series of the function are normally distributed. The unit root tests (the ADF, the D-F (GLS), the Phillips-Perron and the correlogram tests) indicates that the data of all variables are non-stationary at their levels but, they have all been found stationary after the first difference.That is, they allare integrated of order one I(1). Results of Johansen Maximum Likelihood method show that there are two long run cointegratingstable relationships between domestic investment and itspairwise segregated factors as both the trace and max-eigen value statistics are significant for every case. The results of the OLS estimation show that domestic investment of Bangladesh is however influenced by its various factors but financial intermediation and human capital have the negative effect on it of which domestic credit is significant. In contrast, GDP growth rate, FDI, real export and domestic credit have the positive impact on the domestic investment of which real export is significant. The Wald test confirms that the factors are not jointly significant but some of themmay be individually significant for the domestic investment in Bangladesh.VECM shows that the long run causalities exist between financial intermediation, real exports and the domestic investment. The short run effects exist between the GDP growth rate, real exports and domestic investment. There is short run dynamic adjustment to the long run equilibrium in Bangladesh but, divergence with FDI, financial intermediation and domestic credit to domestic investment. The VAR results show that the elasticities of financial intermediation and human capital are negative but statistically insignificant. Real export and domestic credit are statistically elastic in the long run while others are positive but not statistically significant.The GDP growth rate, FDI and financial intermediations are statistically significant in the short run while real exports and human capital are negatively elastic to domestic investment in Bangladesh in the short run. The Granger causality test indicates that there are bidirectional causalities between domestic investment and real export; as well as domestic investment and domestic credit availability in Bangladesh in the short run. Otherwise, there is unidirectional causality between the pair-wise residual variables of the domestic investment function. The impulse response analysis shows that the response of all independent variables is either positive or negative in the short run but in the long run they all are responded towards the domestic investment in Bangladesh. All the components of domestic investment in Bangladesh are volatile but the volatility of FDI is very high. Finally, it may conclude that most of the factors of domestic investment in Bangladesh areunfavourable for it. Thus, it has been an imperative for the govt. to adopt significant initiatives for stimulating domestic investment to enhance economic growth of Bangladesh.

\section{References}

[1] Ahmed, S. (2001). Bangladesh since independence: Development performance, constraints and challenges. Bangladesh Journal of Political Economy, Vol. 15, No. 1.

[2] Akaike, H. (1969). Power spectrum estimation through autoregressive model fitting. Annals of the Institute of Statistical Mathematics, Vol. 21, No. 1, pp. 407- 419.

[3] Bakare, A. S. (2011). The determinants of private domestic investment in Nigeria.Far East Journal of Psychology and Business, Vol. 4, No. 2, Ondo State, Nigeria.

[4] Barro, R. J. \&Sala-I-Martin, X. (1995). Capital mobility in neoclassical models of growth. American Economic Review, Vol. 85, pp. $103-115$.

[5] BB.(1991-2003). Economic trends.[Monthly issues from 06/1991 to 07/2003]. Dhaka: Bangladesh Bank.

[6] BB.(2011). Monetary policy statement July-December 2010.Dhaka:Bangladesh Bank.

[7] BBS.(1995-2005). Statistical year books of Bangladesh. Bangladesh Bureau of Statistics, Dhaka: Government of Bangladesh. 
[8] Beck, T., \& Levine, R. (2004). Stock markets, banks, and growth: Panel evidence. Journal of Banking and Finance, Vol. 28, No. 3, pp. $423-442$.

[9] BER.(2005-2014). Bangladesh economic review. Dhaka:Finance Division, Ministry of Finance, Government of Bangladesh.

[10] Bhuiyan, M. M. (Jan. 7, 2010). Domestic Investment First.On the writing of Jomo Kwame Sundaram, The Daily Star Baangladesh, the Press.

[11] BIDS.(2003). Bangladesh institute of development studies. Dhaka: Bangladesh.

[12] Borensztein, E., Gregorio, J. D. \& Lee, J. W. (1998).How does foreign direct investment affect economic growth?Journal of International Economics, Vol. 45, pp. 115-35.

[13] Coppock, J. D. (1962). International economic stability. New York, USA: McGraw Hill Companies Inc.

[14] Dickey, D. A., \& Fuller, W. A. (1981). Likelihood ratio statistics for autoregressive time series with a unit root. Econometrica, Vol. 49, pp. 1057-1072.

[15] Enders, W. (2004).Applied econometric time series ( $2^{\text {nd }}$ ed.). New York, USA: John Wiley \& Sons Inc.

[16] Fuller, W. A. (1976). Introduction to statistical time series. New York, USA: John Wiley and Sons.

[17] Granger, C. W. J. (1988).Some recent developments in a concept of causality.Journal of Econometrics, Vol. 39, No. 1-2, pp. 199211.

[18] Gujarati, D. N. (1995).Basic Econometrics (3 ${ }^{\text {rd }}$ ed.). Singapore:Mcgraw-HillBook Company Limited.

[19] Gujarati, D. (2011). Econometrics by example. London, U.K: Palgrave Macmillan Publishers Limited.

[20] Gujarati, D. N. (2012).Basic Econometrics (4 ${ }^{\text {th }}$ ed.). New Delhi, India: Tata Mcgraw-Hill Publishing Company Limited.

[21] Haque, T. S. (2013). Effect of public and private investment on economic growth in Bangladesh: An econometric analysis.Research Study Sereis, No-FDRS 5.

[22] Islam, T. S., Hossain, A. M. \&Qamarullah, T. I. B. (2005).A causality analysis of investment and economic growth in Bangladesh.Bangladesh Economic Studies, RURA, Vol. 11, pp. 141-148.

[23] Johansen, S. (1988).Statistical analysis of cointegration vectors.Journal of Economic Dynamics and Control, Vol. 12, pp. $231-254$.

[24] Johansen, S. (1991). Estimation and hypothesis testing of cointegration vectors in Gaussian vector autoregressive models. Econometrica, Vol. 59, No. 6, pp. 1551-1580.

[25] Johansen, S. (1995).Likelihood-based inference in cointegrated vector autoregressive models. New York, USA: Oxford University Press.

[26] Joynal, M. A. (2014, February 03). Investment in Bangladesh. Dhaka: The Financial Express.

[27] Kamrul Hassan, A. F. M., \&Salim. R. A. (2011). Determinants of private investment: Time series evidence from Bangladesh. The Journal of Developing Areas, Vol. 45, No. 1.

[28] Khan, M. A. (1987). The effect of foreign capital inflow on domestic saving and economic growth in Bangladesh: 1972/73 to 1982/83. Chittagong University Studies, Vol. 10, No. 1, pp. 180-193.

[29] Kim, D. D-K., \&Seo, J-S.(2003). Does FDI inflow crowd out domestic investment in Korea?Journal of Economic Studies, MCB UP Limited, Vol. 30, No. 6, pp. 605-622.

[30] Kothari, C. R. (2010). Research methodology: Methods \& techniques ( $2^{\text {nd }}$ ed.). New Delhi, India: New Age International Publishers Ltd.

[31] Lind, D. A., Marchal, W. G., \&Wathen, A. S. (2010). Statistical techniques in business and economics. Irwin, New York: McGrawHill.

[32] Lucas, R. E. (1988). On the mechanics of economic development.Journal of Monetary Economics, Vol. 22, No. 1, pp. 3-42.

[33] Mackinnon, J. G. (1996). Numerical distribution functions for unit root and cointegration tests. Journal of Applied Econometrics, Vol. 11, No. 6, pp. 601-618.

[34] Madala, G. S. (2002). Introduction to Econometrics ( $3^{\text {rd }}$ ed.). New York, USA: John Wiley \& Sons. Ltd.

[35] Matin, K. A. (1987). The effect of foreign capital inflow on domestic saving and economic growth in Bangladesh: 1972/73 to 1982/83. Chittagong University Studies, Vol. 10, No. 1, pp. 180-193.

[36] Perkins, D. H., Radelet, S., Sndograss, D. R., Gillis, M. \& Roemer, M. (2001). Economics of development ( $5^{\text {th }}$ ed.). New York, USA: W.W Norton \& Company.

[37] Perron, P. (1989). The great crash, the oil price shock and the unit root hypothesis. Econometrics, Vol. 47, pp. 1361-1402.

[38] Phillips, P. C. B., \&Perron, P. (1988). Testing for a unit root in time series regression.Biometrika, Vol. 75, No. 2, pp. 335-346.

[39] Qamarullah, T. I. B. (2007). A study of causality between economic growth and private investment in Bangladesh.Social Science Journal, Rajshahi University, Vol. 13.

[40] Reza, S., Rashid, M. A., \&Alam, M. (1987).Private investment in Bangladesh. Dhaka: The University Press Ltd.

[41] Romer, P. M. (1994).The origin of endogenous growth.Journal of Economic Perspectives, Vol. 8, No. 1, pp. 3-22.

[42] Seddighi, H. R., Lawer, K. A., \&Katos, A. V. (2000).Econometrics: A practical approach.Routledge, New York: USA.

[43] Siddiqui, S T. (2014, December 16). FDIs in Bangladesh : Not as bad as suggested but well below the potential. Dhaka: The Daily Independent, the Press.

[44] Stern, N. (2002). The investment climate, governance, and inclusion in Bangladesh. Washington, D.C., USA: World Bank.

[45] Tang, S., Selvanathan, E. A., \&Selvanathan S. (2008).Foreign direct investment, domestic investment, and economic growth in China: A time series analysis. Research Paper No. 19, UNU-WIDER, United Nations University.

[46] Todaro, M. P., \& Stephen C. S. (2003).Economic development ( $8^{\text {th }}$ ed.). Singapore: Pearson Education Inc.

[47] Turabian, K. L. (2003). A manual for writers of research papers, theses, and dissertations ( $7^{\text {th }}$ ed.). Revised by Wayne, C. B. et al., London, UK: the University of Chicago Press.

[48] UNCTAD.(2007). UNCTAD investment brief.Investment Issues Analysis Br., USA: UN Publications.

[49] UNDP.(2010-2014). Human development report. United Nations Development Program, USA: UN Publications.

[50] Wadud, A. M. (2005). Are saving and investment cointegrated? A VAR approach to assess capital mobility in Japan.Bangladesh Economic Studies, RUEA, Vol. 11, pp. 174-181. 